\title{
シンポジウム
}

小細動脈硬化症, 特に脳を中心として

\section{脳出血（動脈破綻）の成り立ち; 血管壊死の再検討*}

\author{
竹 林茂 夫** 金子満 雄***
}

\section{はじめに}

高血圧性脳出血の直接の原因は何により，どの ようにして起こるのか？この問題についてはす でに多くの学説が提唱されてきたが，今日では動 脈破綻説が一般に広く認められている。また，当 該動脈の局所変化として, 英米系動脈硬化説に対 し1,2)，日本，ドイッでは，血管壁の血漿性壊死説 が圧倒的な優位を占めている。 日本では，松岡 ${ }^{3)}$, 大根田 ${ }^{4)}$, 亀山(5) らの研究が, それを代表してい る.

しかし，今日までの本命題に対する病理組織学 的研究は, すべて剖検例を材料とした光顕レベル での検索が主体であって，破綻口やその周辺動脈 壁の詳細な観察はむずかしく, 破綻する前後の動 脈壁の dynamic な動きになると,どうしで speculationの域をでない.

われわれは, 出血発作後, 数時間以内に採取さ れた, 脳出血の原因になっている破綻動脈の電顕 的, 光顕的, 螢光抗体法的観察を重补, 当該動脈 破綻部の状態を検討しているので，今日までの結 果をまとめて報告する.

\section{材料と方法}

高血圧性脳出血にて緊急手術を行なった症例の うちで, 線条体動脈枝の破綻部を止血の目的で電 機凝固する際に，その一部を生検材料として採取 した18症例，18本の小動脈片と，対照として，同 側中大脳動脈の末梢枝で, クモ膜下に分布する前

* 1978 年 5 月第 10 回日本動脈硬化学会において発表

** 福岡大学医学部第 2 病理学教室

*** 県西部浜松医療センター, 脳外科
上側頭動脈枝19症例，19本および脳出血死した 5 例の剖検脳の非出血側線条体動脈の全長を材料と して用いた。

全ての標本は 1 例を除いて，ただちに $1.4 \%$ グ ルタールアルデヒド液に固定し， $1 \% \mathrm{O}_{\mathrm{s}} \mathrm{O}_{4}$ で後固 定後, エポン包埋を行ない, 光顕用, 電顕用と交 互に薄切を重ねて連続切片とし, “光顕用はアルカ リ・メチレン青・フクシン 2 重染色を, 電顐用はウ ラニール・修酸鉛の 2 重染色でそれぞれ検鏡した。 光顕用連続切片からは破綻部付近の再構築模型を 作製して, 動脈走行の立体像を検討した。

また電顕用薄切標本の一部は同時に, JEM. 100 B に ASID, NDS 装置を付けオルテックスの元素 分析装置で $\mathrm{Ca}$ や $\mathrm{Fe}$ などの金属物質の沈着状態 を観察した。

障害動脈壁内へのフィブリン等の侵入の有無を 確めるために, 破綻線条体動脈の 2 本を対照の前 上側頭動脈枝と共に，ただちに PLP 液に固定し， JMD 水溶性樹脂にて包埋し, 薄切後, FITC 標 識した人抗フィブリン血清で染色後, 螢光顕微鏡 で観察した.

\section{結 果}

18例の破綻部を含むと思われた出血巣の線条体 動脈より，6例， 6 個の動脈破綻口を，また，血 腫の増大により 2 次的に破綻した所見を有してい た 3 例， 5 個の小さい動脈破綻部を認めることが できた.

\section{1. 高血圧性一次性動脈破綻：動脈硬化巣から の破綻}

Fig. 1 は 53 歳男性で, 数年来 $260 \sim 130 \mathrm{mmHg}$ に及ぶ高血圧を有し, 出血発作後 3 時間半で採取 


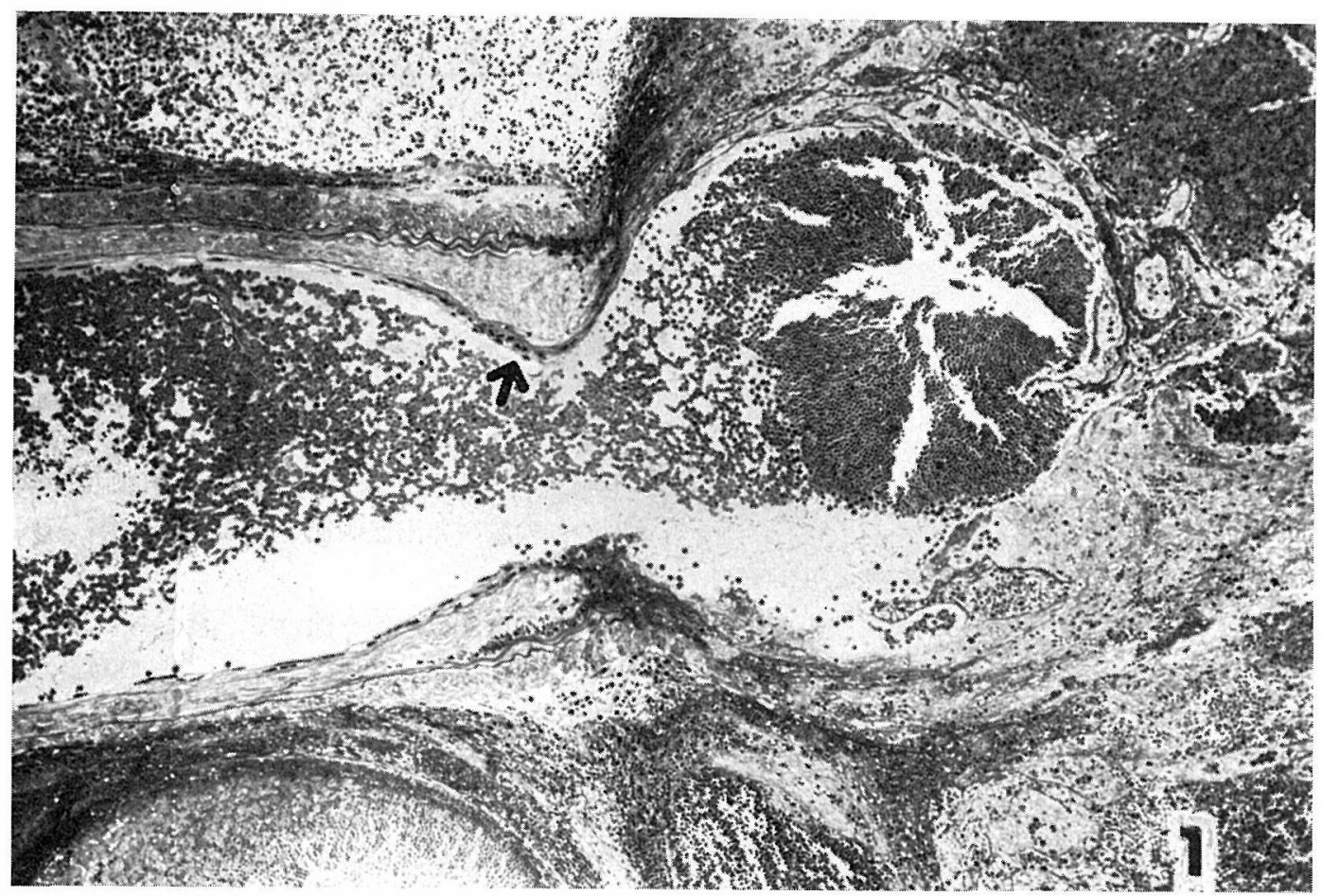

Fig. 1 Rupture at the bifurcation of a lenticulostriated artery meseared $660 \mu$ in diameter. An arrow indicated intimal chusion at the bifurcation.

された直径 $660 \mu$ の線条体動脈の分岐部での破綻 を示している．当該動脈壁には中膜の厚さに匹敵 するくらいの強い内膜肥厚を認めるが，内腔は全 般的に抎張ぎみであった。 この破綻口の一部を拡 大したものが, Fig. 2 で, 中膜竻細胞にはかなり の変性・萎縮, あるいは部分的消失が認められる が，内膜の平滑筋はなお比較的保たれている。 ま た, 破断した内弾性板は充分な弾力性を有して, 手前方向に収縮しているのが明瞭に確められる。

しかし，2 枚の写真のどこにも硝子様物質や類線 維素物質は認められない。この例の場合，あるい はこうした血獎由来物質は破綻時に血液と共に血 塊中に飛散したとも考えられるので，他の例につ いて，この点の検討を加える.その 1 例を Fig. 3, 4, 5 に示している.

本例は37歳, 男性で, $180 \mu$ の線条体動脈枝の 破綻を示している. 破綻部の内弾性板は突然断裂 し，その電顕写真を Fig. 5 に示している. 形態的 にも内弾性板は正常で横断状態で破断している. 一方, 破綻部の中膜層の断片は, なお出血塊中に
断片的に追跡できる (Fig. 3 矢印)，これらを逐次， 電顐的に観察していくと， Fig. 4 に示すように内 腔面にはすでに内皮細胞, 内弾性板はなく, 中膜 筋細胞やその基底膜が栓球性血栓と直接相接して いる. その部の中膜筋細胞には強い不規則な萎縮, 消失と, 逆に筋細胞を取り巻く基底膜物質の著明 な増加を認める。 また, 筋細胞間には dense granules, vesicules が堆積しているが，どこにも，ま たどの切片にも電顕的に血漿成分の侵入, 堆積は 認められなかった。

中膜筋細胞のかかる変化は破綻に関係した線条 体動脈では非破綻部でも同様，広範に認められた。 その代表的なものを Fig. 6 に示している. 寸なわ ち, 破綻動脈に共通している所見はそれが中膜で あれ, 肥厚した内膜であれ, 平滑筋細胞の不規則 な变形, 萎縮, 部分的消失であり, 同時に細胞を 取り巻いて, 基底膜様物質の著明な増加があり, 細胞間には種々な細胞屑や脂質類が dense granules, vesicules として婎積していた. 本論文ではこ のような平滑筋細胞を主体とした変化を動脈壁の 


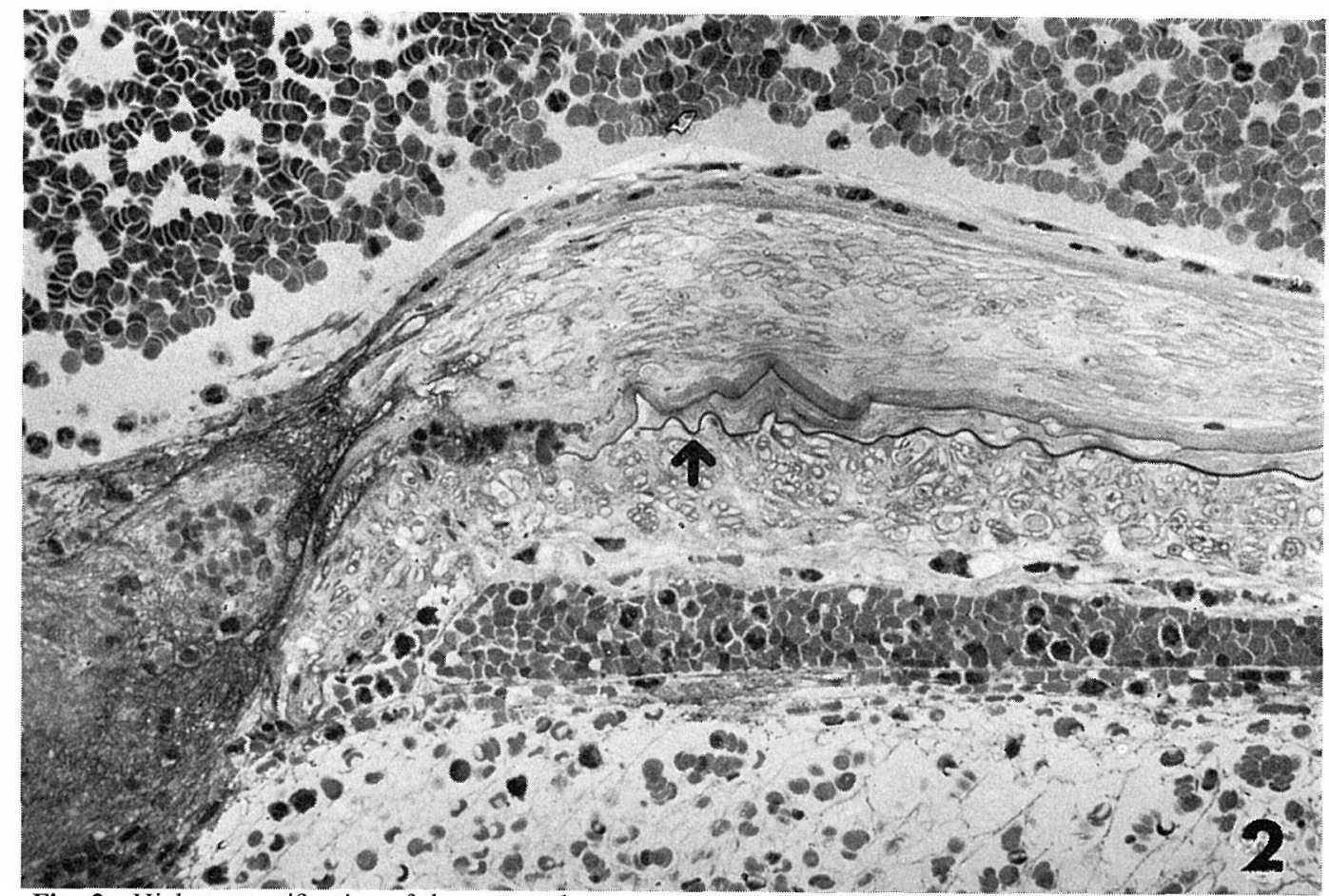

Fig. 2 Higher magnification of the ruptured artery. Note remarkable intimal thickening. Smooth muscle cells in media represent obvious exhausted degeneration, but in intima is less severe. Original elastic lamella is elastically shrinked at the ruptured edge $(\uparrow)$.

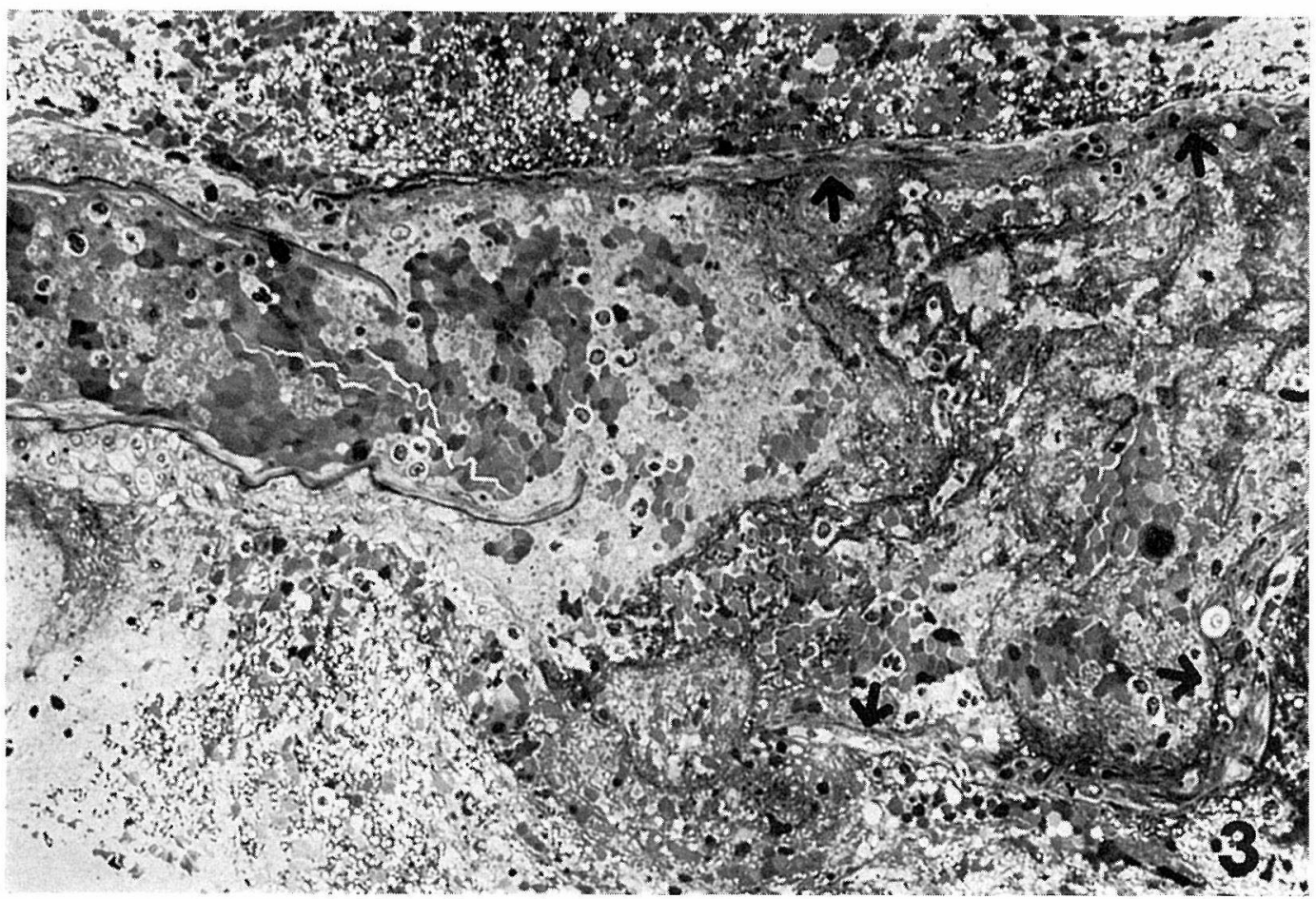

Fig. 3 A lenticulostriated artery $180 \mu$ in diameter rupture at the bifurcation, showing sharply disrupted internal elastic lamellae. However, some fragmented arterial walls can be detect in the hemorrhage $(\uparrow)$. 
動脈硬化 Vol. 6 No. 4 January 1979

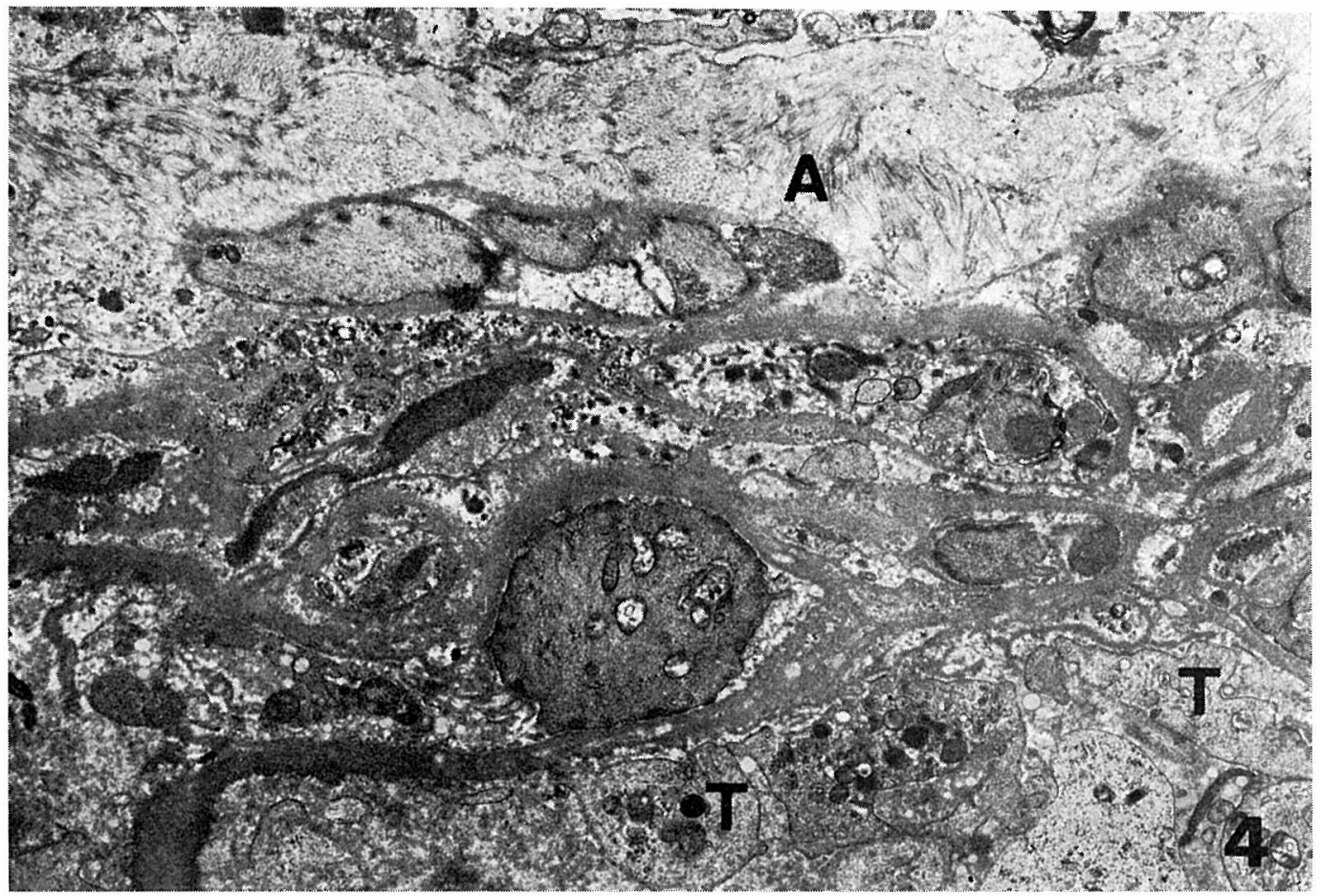

Fig. 4 Fine structure of the fragmented arterial wall in the blood clot in Fig. 3. Medial smooth muscle cells represent exhausted degeneration in various grades. A: adventitia, T: thrombocyte, 7,000 $\times$

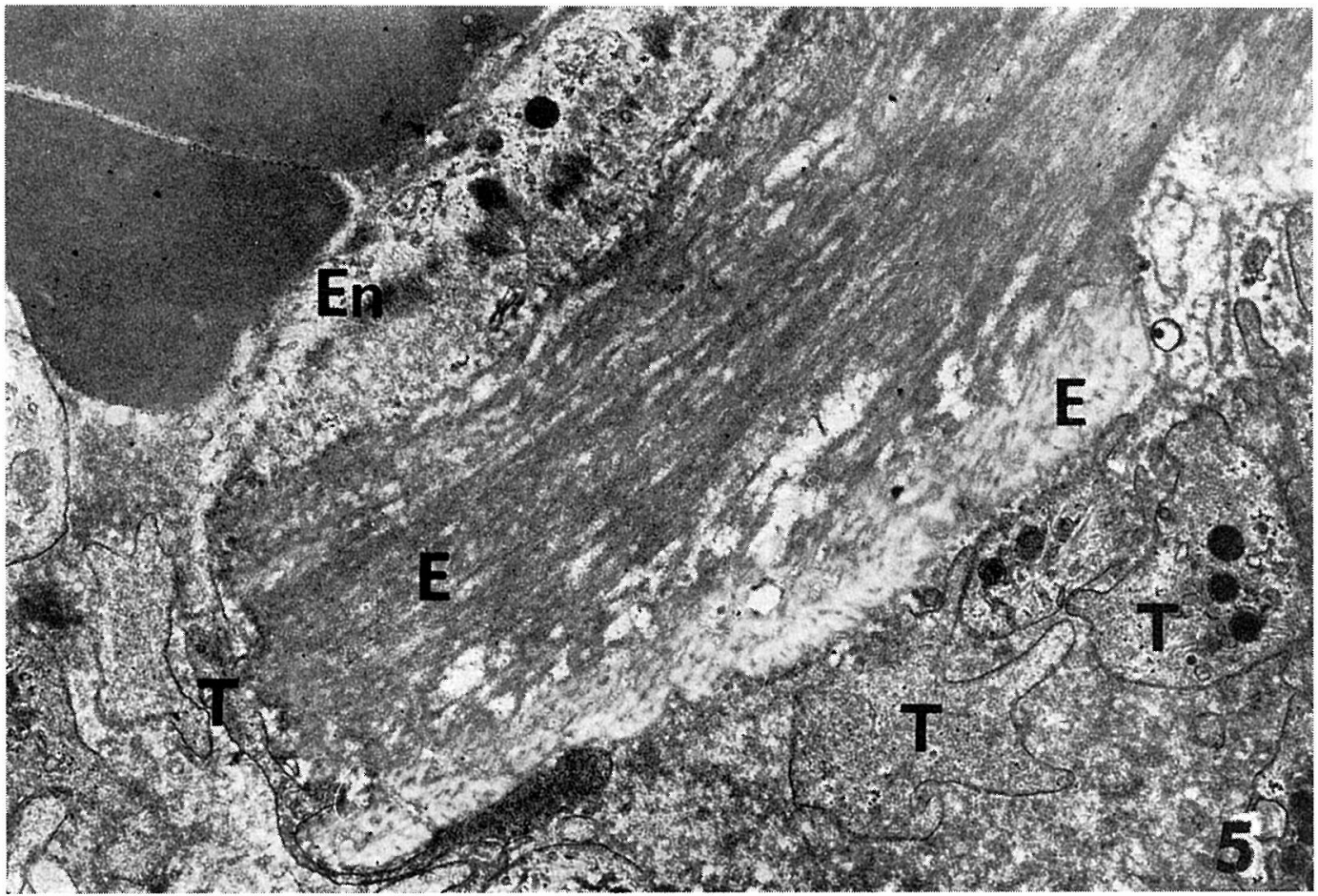

Fig. 5 Elastic lamella (E) which is morphologically normal, is sharply cutting off at the ruptured ostium, and thrombocytes to adhere the cutt surface. En: endothelial cell, T: thrombocyte, $9,000 \times$ 


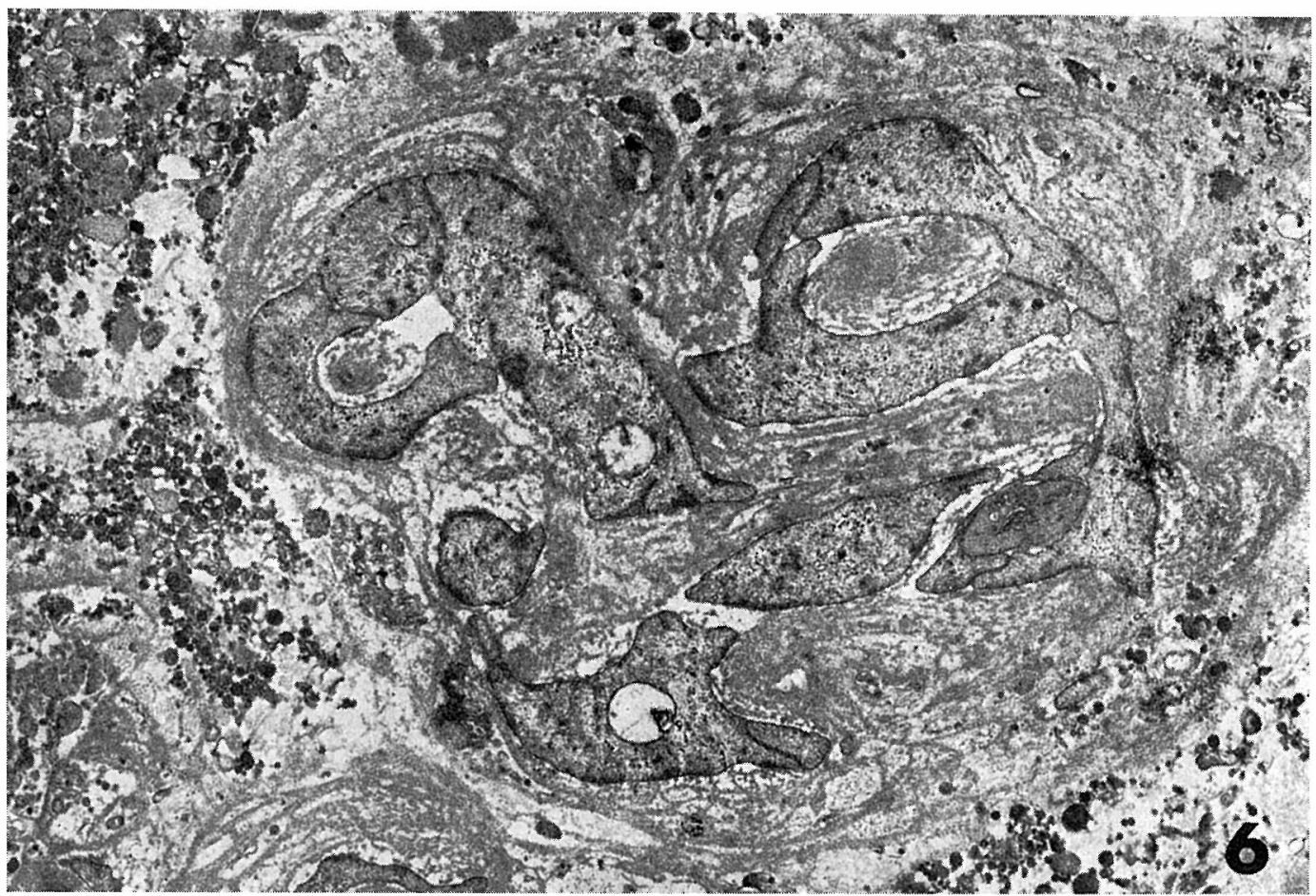

Fig. 6 Typical exhausted degeneration of medial smooth muscle cells, showing irregularly atrophic or fragmented cytoplasm of the smooth muscle cells, and increase of basement membranoid materials, 7,000x

「消耗性変化」と仮称した.

症例によっては，破綻口付近の内膜に食細胞由 来の foam cell を始め, 多数の脂質の沈着した内 膜肥厚 (粥状硬化) を示している例もあったが, 筋細胞の消耗性変化は共通した所見として認めら れた.こうした病巣部にフィブリン等の血漿成分 が果たして全く関与してないかどうかを螢光抗体 法で検討したのが，Fig. 11 である。いずれの場 所にも壁内に侵入した血漿成分（フィブリン）を 証明することはできなかった。

2. 小動脈瘤（血管壊死，血獎性動脈壊死）よ りの破綻

6 症例， 6 個の破綻口のうち，2 個は Fig. 7 に 示すように明らかに小動脈瘤よりの破綻であった。 ただ，この小動脈瘤も薄切部位をずらすと，血管 壊死 (松岡) や血槳性動脈壊死（大根田）と区別 できない像を示していた。本例は56歳, 女性で, 出血発作後 3 時間で採取, 固定された直径 $250 \mu$ の動脈から $150 \mu$ の分枝が出る分岐部に認められ
た最大直径 $1,500 \mu$ に達する小動脈瘤で, その 1 部 に明らかな破綻を認める。この小動脈瘤に連なる 2 本の動脈にはいずれもかなり強い内膜肥厚がみ られた. 小動脈瘤の壁には帯状にフィブリンの沈 着が認められ, その内外には好中球, 単球, リン パ球などがかなりの程度に浸潤していた。

限局性，不規則な露状に拡大してくる小動脈瘤 もその薄切の方向や部位により，あるときは血管 壊死と区別できない切片が認められ，多彩な形態 を示すが，電顕レベルでの観察では一段と多様性 に富んできた。すなわち，単なる数層の層状フィ ブリンでできている所，血液由来細胞がそれにか らまり合っている所 (Fig. 8), 内皮細胞が部分的 に再生し, 幼弱平滑筋細胞もフィブリン塊に侵入, 増殖し始めているもの (Fig. 8), 脂質を多量に有 する食細胞系の foam cell を認めたり (Fig. 8), 細

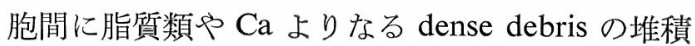
した所，いわゆるフィブリノイド物質の帯状に沈 着した所，断片化した弾力線維，膠原線維と共に 


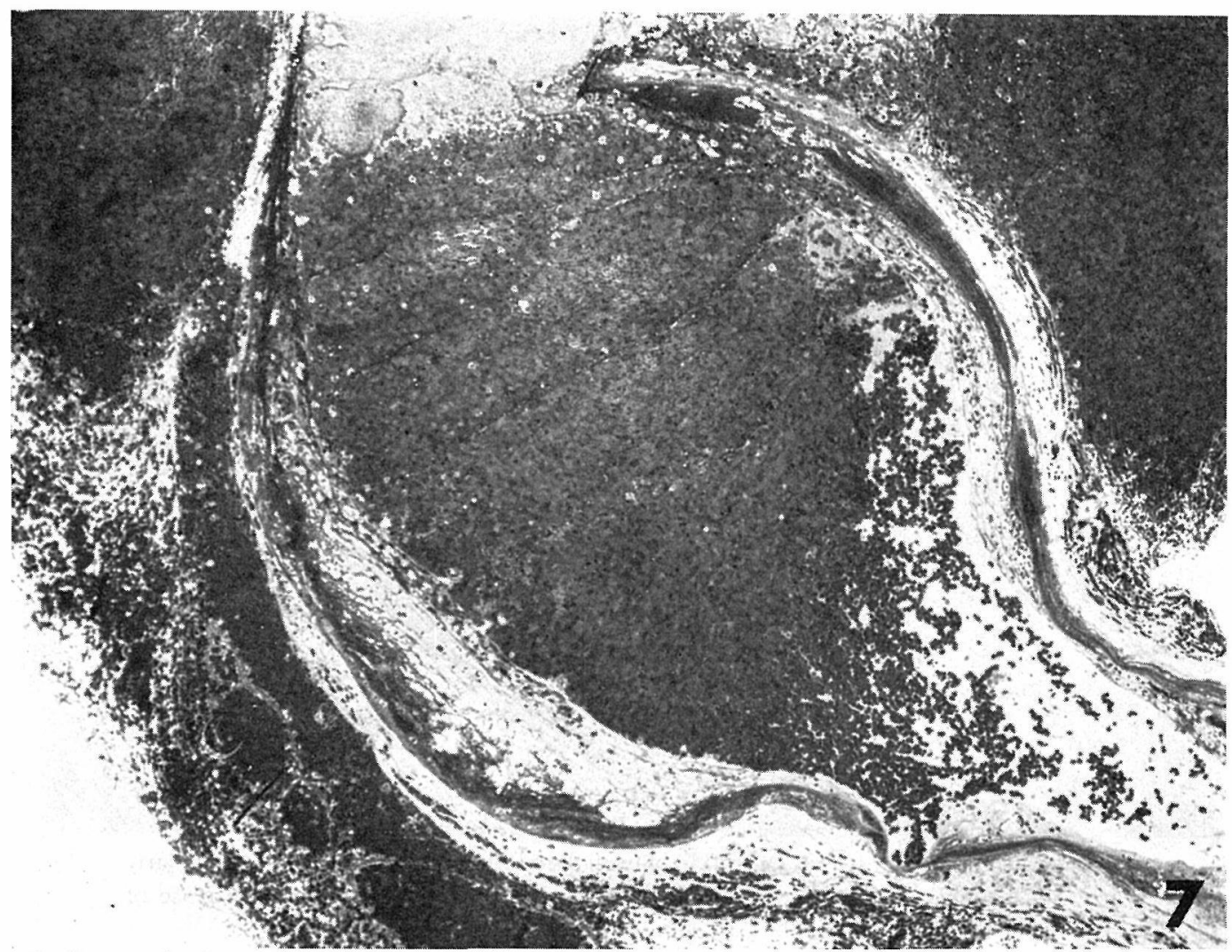

Fig. 7 Ruptured microaneurysm meseared $1000 \mu$ in diameter represent in this photo. Note dense, band-like deposition of fibrin. Arteriosclerosis in considerable grade is seen in the afferent artery at the right under corner.

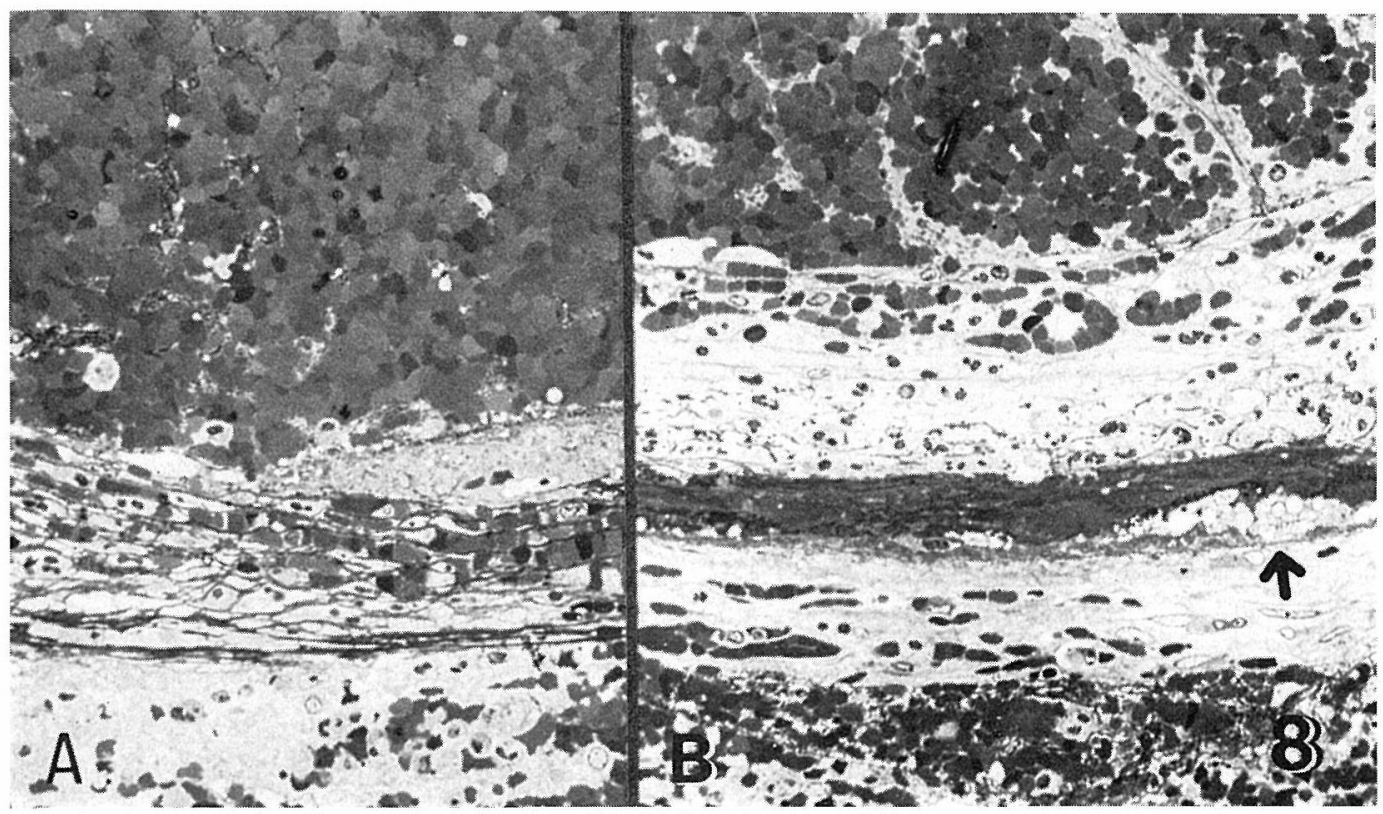

Fig. 8 A: Aneurysmal wall comprised thin lamellar fibrine sheats. B: The walls are mixed up of dense fibrinoid materials, and considerable numbers of leukocytes and lipid-laden form cells $(\uparrow)$. 
脳出血（動脈破綻）の成り立ち; 血管壊死の再検討

平滑筋細胞の一部を認める所 (Fig. 8) など誠に多 彩な所見を呈していた.その付近の壁内外の細胞 間に堆積している electron dense granules の中に は，明らかに $\mathrm{Ca}$ と同時に Fe を同定することが
できた (Fig. 9, 10).

以上のような小動脈瘤（あるいは血管壞死）の 電顕像は脳以外の臓器動脈にみられる高血圧性フ イブリノイド壊死，あるいは硝子様肥厚の像とは

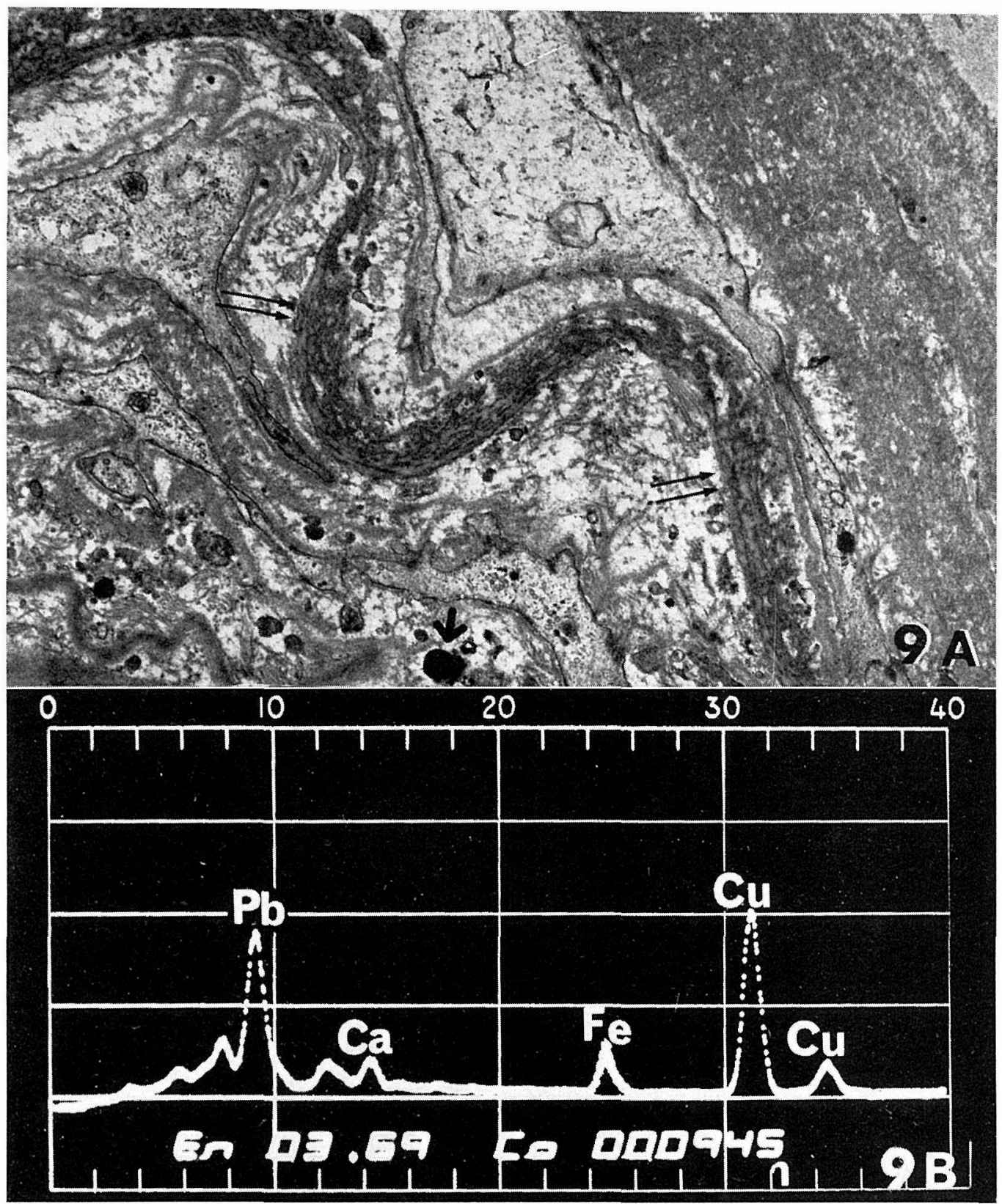

Fig. 9 At the proximal portion of the aneurysm, original elastic lamella is fragilely remained $(\uparrow \uparrow)$, but the media is severe destryed, and several electron donse granules $(\uparrow)$ which had been detected by electron microscopic energy analyer showing in Photo B, are found in the intercellular matrix. 7,000 $\times$ 


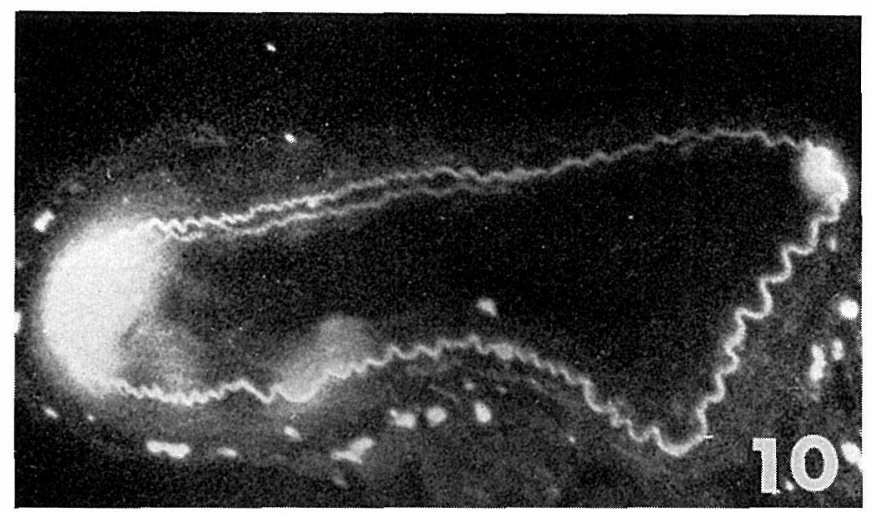

Fig. 10 An immunofluorescenced micrograph showing negative anti-fibrine fluorescence in the media of which the artery biopsied from the cerebral hemorrhage, and which had be microscopically comfirmed to be remarkable exhausted degeneration.

きわめて異質な，奇異な感じを抱かせるものであ 万.

\section{3. 対照動脤の場合}

1) 前上側頭動脈枝

線条体動脈に破綻を有し，周辺の動脈壁にはき わめて強い笳細胞の消耗性変化を認めながら, 同 じ中大脳動脈の同側分枝である.クモ膜下に分布 する前上側頭動脈枝には全例とも，経年的に内膜 肥厚な進行傾向走示すものの, 筋細胞の消耗性変 化は極めて軽微であった。

2) 非出血側線条体動脈

脳出血死した 5 例の非出血側線条体動脈全長の 光顕観察の結果は Fig. 11 に要約される. 寸なわ ち, Fig. 11 の A, B \&同一症例，同一線条体動脈 で，A が起始部寄り，B が Putamen を貫く部位 で，B の中膜に強い“消耗性変化”在認める. 写 真はいずれも, Epon 包埋, Semithin Section, ア ルカリ 2 重染色標本よりのもので, 通常のパラフ イン包埋, HE 染色では雨者にほとんど差異を認 めず，ほほ正常として見のがされる所見である.

こうした中膜筋細胞の “消耗性変化”の他に3) に示すように年龄が進むと foam cell の内膜に集 合した脂質類の堆積（粥状硬化宩）も同時によく 認められた。

\section{考案}

今日，多くの人によって高血圧性脳出血の直接 原因と考えられている動脈壁の障害には，Micro- aneurysm (Charcót; 18687), Beitzke; 19378)), Arteriolonekrose (Stammler; 19369)), Angionekrose (Westphal; $1926^{10}$ ), plasmatische Gefässzerstörung (Wolf；193711) , 血管壊死 (松岡; 1938 ${ }^{12}$ ), Hyalinose (Scholz; 193813), Spatz; 193914), Medianekrose (Nordmann; 194315) , fibrinoid arteritis (Feigin; 195616) ), fibrinoid Nekrose (Margolis; 1966 ${ }^{17)}$ ), lipohyalinose (Fisher; 1967.8)), 血獎性動脈壞死 (大根田；1970 19)）などの呼び名で表現されている ものがある。その中には同じものもあれば，多少 異質なものもあろら。しかし，これらが共通して ることは限局性病宩で，しかも種々の程度に内腔 の扡大を伴う壊死性, 類線維素性変化の強いもの を呼んでいる点である。松岡も1939年の原著30で， すでに彼が提唱した血管壊死と小動脈瘤（真性動 脈瘤；松岡）とは本質的には同一の性格を有する 変化であると述べており，大根田 ${ }^{19)}$ も血管壊死 $\rightarrow$ 血漿性動脈壞死 －小動脈瘤は一連の変化であるこ とを認めている.ただ，その病巣の大きさや薄切 方向, 薄切部位, 病巣の新, 旧性などにより,き わめて多彩な形態党取り得, その解釈により, 従 来, 色々な学説が提昌されてきた感じがある. 事 実，小動脈瘤はそれ連続切片で再構築すると， きわめて歪な形態起しいること(松岡 ${ }^{20)}$, Cole $\&$ Y $\left.{ }^{21}{ }^{21)}\right)$ ，往々周囲に浸潤細胞や siderophage, foam cell 老見る (松岡 ${ }^{20)}$, 大根田 ${ }^{19)}$, Stehbens ${ }^{2)}$, 内腔を被う内皮細胞は極めて不完全である（Rus$\mathrm{sel}^{22)}$, Cole, Yates ${ }^{23)}$, 大根田 ${ }^{19)}$ ), 内腔に血栓形成 

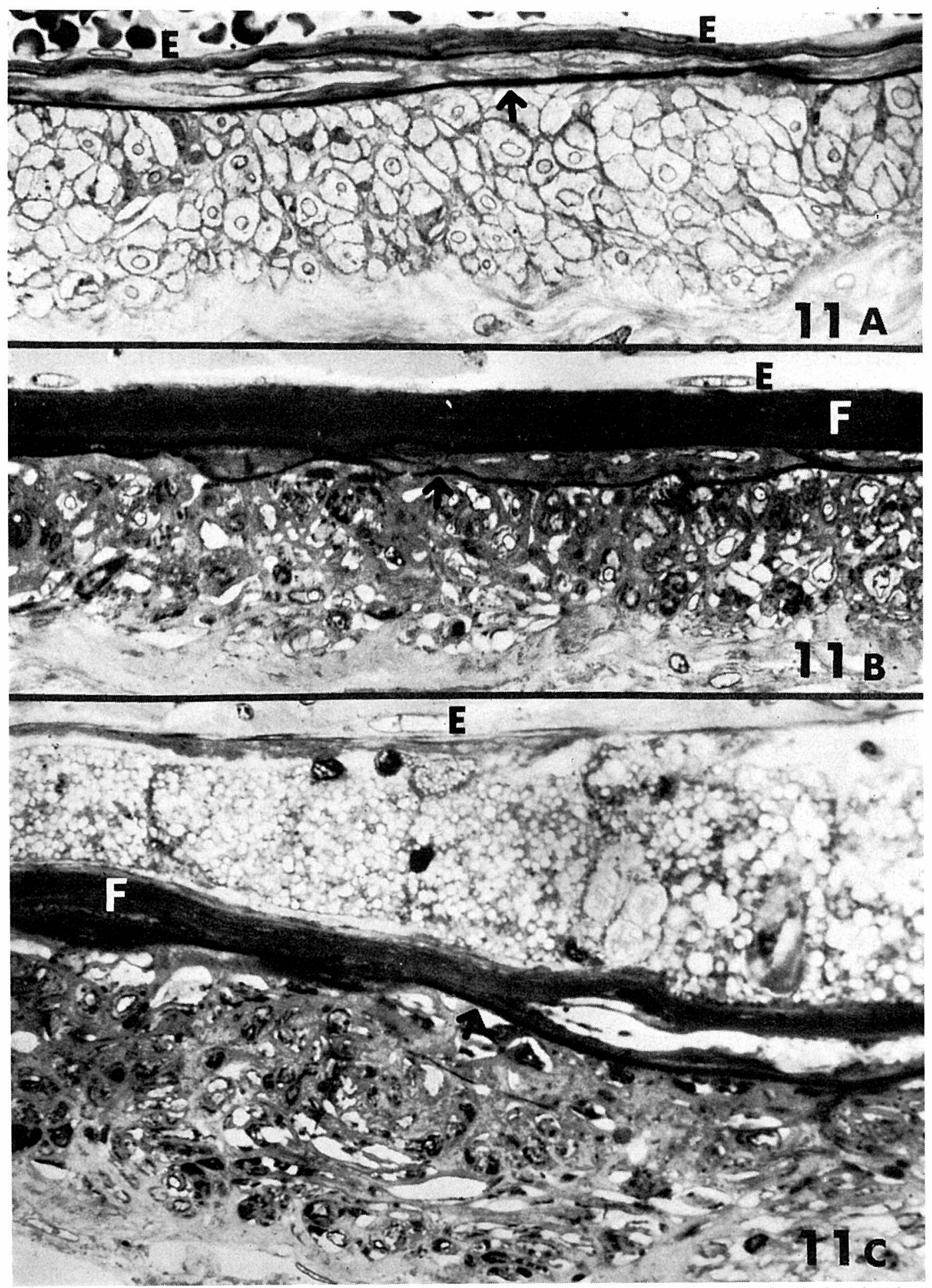

Fig. 11 Lenticulostriated arteries in 74 year-old, male who die from massive hemorrhage from lenticulostriated artery of another side. A: Proximal portion of the lenticulostriated artery in which the media smooth muscle cells are quite normal, and only mild intimal thickening is noted. B: The same lenticulostriated artery nearby the putamen showing severe exhausted degeneration in media smooth muscle cells. Thickening of the intima is similar to that in photo $A$, except increase of fibrillar component of elastic fibers (F). C: The same lenticulostriated artery, distal portion, represented accumulation of numerous lipid-laden foam cells in intima (so called atherosclerosis), and severe exhausted degeneration of the media smooth muscle cells. $\mathrm{E}$ : endothelium, $\uparrow$; internal elastic lamella. 
をよく認める (大根田 ${ }^{19)}$ ) などの特徴が知られて いる. 今回のわれわれの電顕レベルの観察でも上 記の変化の他に, 菲薄化した動脈瘤の壁は層状の フィブリン網のみでなっているもの，それに浸潤 細胞のからみ合っているだけの所がある一方，多 数の脂質を食した macrophage 由来の foam cell の他に細胞間には脂質原, $\mathrm{Ca}, \mathrm{Fe}$ が dense granules として沈着しており, 脳以外の臓器動脈の 高血圧性類線維素変性の電顕像と比較するときわ めて異質な所見であった ${ }^{24)}$. まして細胞成分もな いフィブリ層のみよりなる壁が出血準備状態にあ る障害動脈壁の姿であると理解することはきわめ て不自然な考えであろう。

以上の所見を総合すると, 内腔桩大と類線維素 変性を伴う限局性の小細動脈病変は, subclinical に経過した小出血巣, 不完全出血巣の再疎通状態 と考えるのが一番妥当のように思う. Cole \& Yates ${ }^{23)}$ \& Subcortical に多発してみられる小動 脈瘤の多くは, “出血後の再疎通状態の可能性を示 唆している．ちなみに小動脈瘤の出現しやすい動 脈は，70～200 $\mu$ 程度の小さい動脈であること (松岡 ${ }^{4,20)}$ ) はそのまま小出血で subclinical に経過 する可能性を示唆し，また一般に小動脈瘤の出現 年齢と脳出血の出現年齢がきわめてよく一致し,

$\left(\right.$ Cole \& Yates ${ }^{23)}$, Russe122,25)), 年齢的に脳出血 に先行して小動脈瘤が発見されることのないこと なども同じ示唆を与える所見と考えられる．浸潤 細胞の有無や多少も病巣の古さと十分関連さして 考えることができよう。ここで，われわれは，わ が国の先達によりなされた, すぐれた業績を否定 しさろうというのではない。ただ，今日までの限 られた生検材料には動脈破綻に移行する前段階, 準備段階としての類線維素変性, 血管壊死にはま だ遭遇せず，逆に Subclinical に経過した小出血 または不完全出血の再疎通像と理解できるホ動脈 瘤（血管壊死）からの再破綻を確認しているとい うことである.この問題の結論はなお今後に残さ れよう。

一方, 今回の検索で, より重要なことは血漿成 分の関与しない，すなわち動脈硬化症の状態だけ で明らかに大きな破綻性出血を認めたことにある。 しかも頻度的には血管壊死一小動脈瘤からの再破
綻よりも明らかに多いように見える．

もちろん, 脳出血患者は対照に比べ明らかに脳 動脈硬化症の強いことが知れている じ動脈硬化症で脳硬塞, 脳塞栓など閉塞性に移行 するものと破綻性出血を惹起するものとの相違, すなわち, 動脈硬化症の質的検討がここで重要に なってくる. 事実, 血管壊死は拡張性内膜肥厚に 好発することを大根田もすでに指摘しているよう に ${ }^{19)}$, 破綻を有する線条体動脈は内膜肥厚がある うとなからうと強い筋細胞の消耗性変化を有し, 内腔は一般に拡張ぎみになっていたのに対し，内 腔狭窄に連る増殖を主体とするものは内膜での筋 細胞の増殖, 膠原線維, 弾力線維, 基質類の増多 (すなわち増殖性変化) が中膜の筋細胞の消耗性変 化をはるかに凌駕して強く認められた. ただ同一 線条体動脈でも, その枝が異なれば一方は消耗性 変化が強く, 他の枝では逆に強い増殖性変化を示 す症例には往々遭遇している. また, 破綻部の消 耗性変化よりも明らかに強い変化を有しながら, 破綻していない場所もかなり認められる。このこ と自体, 当該動脈壁の破綻の原因には壁の障害度 以上に血液自体の性状 ${ }^{26)}$, 血圧や静脈系を含む血 行動態の急変 ${ }^{19,27}, H^{2}$ ypoxia ${ }^{19)}$, 腎性因子 ${ }^{20,29)}$,

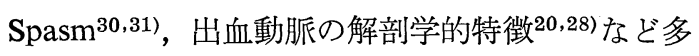
数の要因の集合が必要と考えられる.

われわれは, 最近, 人の脳動脈の神経支配を調 べ, 従来の知見とは逆に脳血管が交感, 副交感神 経の強い支配をうけ，特に基底核に分布する動脈 により強いことを確かめている ${ }^{32}$. 線条体動脈壁 に認めた平滑筋細胞の消耗性変化は明らかに動脈 硬化症の一つの所見ではあるが, 脳以外の臓器動 脈でこれ程強いものを認めることはきわめてまれ である. 今後の重要研究課題の一つであろう.

\section{結論}

高血圧性脳出血の緊急手術時に採取された線条 体動脈の電顕観察で, 6 症例 6 個の主破綻口と, 3 症例 5 個の 2 次性破綻口を見いだし, 連続切片 観察の結果, 次の結論を得た。

1）高血圧性脳動脈破綻の原因には血管壊死な ど, 従来考えられていたものの他に血漿成分の関 与のない, 中膜平滑筋細胞の消耗性変化を主体と 
する硬化性変化の強い動脈が分岐部付近で直接破 綻してる.頻度としてはこの型のものが最も多い。

2）小動脈瘤, または血管壞死, 血漿性動脈壞 死よりの破綻例も認められたが, 頻度としては少 ない。

3）小動脈瘤, または血管壊死, 血漿性動脈壊 死は Subclinical に経過した小出血, 不完全出血 の再疎通状態である可能性がきわめて濃い.

4）高血圧者の線条体動脈法破䋎の有無に関倸 なく, Putamenなぞ末梢附近で極めて強い中膜の 硬化性変化(消耗性変化)を呈し, 同じ線条体動脈 でもその起始部近くでは極めて軽い所見を示した。

5) 出血例の線条体動脈溞く認めた笳細胞の 消耗性変化は動脈硬化症の一つの形態的所見であ るが，その程度は他臟器動脈化例をみないほど強 い.

6）消耗性変化の成因について言及し，同時に 脳出血の成り立ちに, 局所動脈壁障害の他に多数 の重要因子群が考慮された。

\section{文 献}

1) Ellis, A. G.: The pathogenesis of spontaneous cerebral hemorrhage, Proc. Path. Soc. Philadelphia 12: 197-212 (1909).

2) Stehbens, W. E.: Pathology of the cerebral blood vessels, CV Mosby Co. Saint Louis, pp 284 (1972).

3) Zimmerman, H. M.: Cerebral apoplexy: Mechanism and differential diagnosis. New York State J. Med., 49: 2153-2157 (1949).

4) 松岡 茂：脳卒中症の病理; 血管病変を中心として, 日病会誌 39: 1-10 (1950).

5) 大根田玄寿：脳出血の病理; 血管病変を中心として, 日病会誌 59: 27-56 (1970).

6) 亀山正邦：脳卒中例の血管病変; 脳出血を中心とし て, 臨床神経学 4: 387-401 (1964).

7) Charcót, J.-M. et Bouchard, C.: Nouvelles recherches sur la pathogenie de I'hemorrhagie cerebrale. Arch. Physiol. Norm. Path., 1: 110-127, 643-665 (1868).

8) Beitzke, H.: Die Rolle der kleinen Aneurysmen bei den Massenblutungen des Gehirns. Verh. Dtsch. Path. Ges., 29: 74-80 (1937).

9) Staemmler, M.: Zur Lehre von der Entstehung des Schlaganfalles. Klin. Wschr., 15: 1300-1306 (1936).

10) Westphal, U. and Bär, R.: Über die Entstehung des Schlaganfalles. I. Pathologisch-anatomische Untersuchungen zur Frage der Entstehung des Schlaganfalles. Dtsch. Arch. Klin. Med., 151: 1-30 (1926).
11) Wolff, K.: Untersuchungen und Bemerkungen zur Lehre von der hypertonischen apoplektischen Hirnblutung. Virchows Arch., 299: 573-628 (1937).

12）松岡 茂：脳出血及軟化の研究(第 1 報).人脳に於 ける血管分布とその組織学的変化特に高血圧者の脳 内血管病変. 日病会誌 28: 381-385 (1938).

13) Scholz, W. und Nieto, D.: Studien zur Pathologie der Hirngefässe. I. Fibrose und Hyalinose Zschr. ges Neurol. Psych., 162: 675-693 (1938).

14) Spatz, H.: Pathologische Anatomie der kreislaufstörungen des Gehirns. Zschr. Nrurol., 167: 301357 (1939).

15) Nordmann, M.: Referat über die Spontanblutungen in menschlichen Gehirn. Verh. Dtsch. Path. Ges., 29: 11-54 (1937).

16) Feigin, I. and Prose, P.: Hypertensive fibrinoid arteritis of the brain and gross cerebral hemorrhage. A form of "hyalinosis". Arch. Neurol., 1: 112-124 (1959).

17) Margolis, G.: The vascular changes and pathogenesis of hypertensive intracerebral hemorrhage. In: Cerebrovascular disease, Ass Res. Neru. Ment. Dis., 41 : 73 (1966).

18) Fisher, C. M.: Cerebral miliary aneurysms in hypertension Am. J. Path. 66: 313-329 (1967).

19) 大根田玄寿：脳出血の病理, 文光堂. 東京, 1974.

20) 松岡 茂: 脳出血の病理学的研究, 精神学誌 43: 4593 (1939).

21) Cole, F. M. and Yates, P. O.: The occurrence and significance of intracerebral micro-aneurysms. J. Path. Bact., 93: 393-411 (1967).

22) Russell, R. W. R.: Observations on intracerebral aneurysms. Brain, 86: 425-442 (1963).

23) Cole, F. M. and Yates, P.: Intracerebral microaneurysms and small cerebrovascular lesions. Brain 90: 759-768 (1967).

24) Takebayashi, S. and Kamio, A.: Ultrastructural studies on human arteriosclerosis. Comparison between hypertensive and normotensive groups. Acta. Path. Jap., 19: 479-499 (1969).

25) Russell, R. W. R.: Pathogenesis of primary intracerebral hemorrhage. in Cerebral Vascular Diseases, Sixth Conference (J. F. Toole, R. G. Siekert and J. P. Whisnant), 152-160, Grune \& Stratton. New York (1968).

26) 東儀英夫, 山之内博, 小川 真, 内山伸治, 田淵正 康, 亀山正邦：老年者脳卒中の発症前の血圧, 血液 成分の特徵. 日内誌 65: 765-781 (1976).

27) Takeshige, Y.: Die Bedeutung des Venensystems für die Hämodynamik des Hirnstammes. Anat. Anz., 125: 166-192 (1969).

28) Jain, K. K.: Some observations on the anatomy of the middle cerebral artery, Canad. J. Surg. 7: 134-149 (1964).

29) 池田正男, 藤井 潤, 関 顕: 高血圧脳出血の成 因, 特に脳の細・小動脈の急性血管病変 (フィブリ 
動脈硬化 Vol. 6 No. 4 January 1979

ノイド壊死) のなりたちに関する血管障害因子，最 新医学 29: 1221-1238 (1974).

30) Globus, J. H. and Epstein, J. A.: Massive cerebral hemorrhage: spontaneous and experimentally induced. Proc. First Int. Congr. Neuropath. 1:
289-299 (1952).

31) Schwartz, P.: Cerebral apoplexy, types, causes, and pathogenesis, Charles C. Thomas, Publisher. Springfield, Ill. (1961).

32）竹林茂夫：未発表 


\title{
Summary
}

\section{Ultrastructural Aspects of the Ruptured Arteries in Hypertensive Intracerebral Hemorrhages in Man: Re-evaluation of Microaneurysm (Angionecrosis) as a Causal Genesis}

\author{
Shigeo TAKEBAYASHI* and Mitsuo KANEKO** \\ *Department of Pathology Fukuoka Univ. Medical School \\ **Neurosurgical Division, Hamamatsu Medical Center
}

On the emergency surgery against hypertensive intracerebral hemorrhages of 18 patients, arteriolar biopsies were performed from each lenticulostriate arteries with ruptured hemorrhages. They were, then, serially sectioned and were examined by electron-microscopy as well as light microscopy.

The examination revealed six disrupted ostiums of the arterial walls causing massive hemorrhages, in 18 individuals. Four of them were ruptured at bifurcations of the arteries with arteriosclerotic changes which were characterized by smooth muscle cell degeneration in media as well as in intima, if thickened, and termed "exhausted degeneration" in this paper. That is, irregular or moth eaten-like atrophy of the smooth muscle cell with remarkable increase of its basement membranoid materials. The internal elastic lamella was sharply disrupted without any previous alterations at disrupted ostium. Ultrastructurally, there is, however, neither fibrinoid nor insudative changes at the disrupted portion, as a previous alteration. The disruption was not respected to lipid deposition in intima and/or media.

Microneurysm ("angionecrosis") was another cause of the rupture in two remained patients.
The wall of the microaneurysm, however, ultrastracturally comprised quit various components; only lamellar fibrin sheats or with intermingled inflammatory cells and/or lipophage, or with partially or completely regenerated endothelium and imigration of immatured smooth muscle cell (or indeterminated cell), intercellular deposition of calcium as well as ferrum as an electron dense granule, which were detected by electron microscopic x-ray analyzer. Those are quit different from that in hypertensive fibrinoid thickening of arterioles in other organs. Thus, the microaneurysm which thought causally relate to primary intracerebral hemorrhage, is rather easily understandable to be a resorbed state of a smaller or incomplete, subclinical hemorrhage.

On conclusions, hypertensive intracerebral hemorrhages occure more frequent from primary rupture of arteriosclerotic lesions than from microaneurysm which is more likely to be old recanalized, small hemorrhage.

Key words: intracerebral hemorrhage, microaneurysm, arteriosclerosis, exhausted degeneration, medial smooth muscle cell, angionecrosis 